Araştırma Makalesi / Research Article

\title{
MANAGEMENT MODEL OF ZAKAT COLLECTION AND ITS DISTRIBUTION FOR ZAKAT AGENCY
}

\section{Rizal FAHLEFI 1 Asyari HASAN2 Alimin ALIMIN ${ }^{3}$}

\begin{abstract}
Collection and distribution are two main activities in the zakat agency. The good management of zakat collection and its distribution makes zakat reach its main goal, that is muslim welfare. The research had the purpose of describing the managerial steps of zakat collection and its distribution taken by National Zakat Agency of regency/city in the province of West Sumatera in Indonesia. It uses qualitative research approach and case study method with non-structured interviews, observations, and documentation studies. The research results indicate that the management model of zakat collection and its distribution is by using steps of POSCAC which cover the application of planning (P), organizing (O), staffing (S), coordinating $(C)$, actuating $(A)$, and controlling $(C)$. The principles of POSCAC has been applied by National Zakat Agencies of regency/city in the province of West Sumatera, Indonesia, in zakat collection and its distribution.
\end{abstract}

Keywords: Management, Zakat Collection, Zakat Distribution, BAZNAS

\section{Introduction}

The authorized zakat collector institution formed by the Indonesian government is National Zakat Agency (Badan Amil Zakat Nasional 'BAZNAS') with its central-down to regency/city level offices. The management of zakat by BAZNAS is regulated in a Law of the Republic of Indonesia number 23 of year 2011. According to the law, BAZNAS is a nonstructural government institution which is independent in nature given competence in doing the job of nationally managing zakat. In the course of the execution of zakat management at the regency/city level, the regency/city level BAZNAS is formed to do the job and function of BAZNAS in the regency/city concerned.

\footnotetext{
${ }^{1}$ Institut Agama Islam Negeri Batusangkar, Indonesia, rizalfahlefi@iainbatusangkar.ac.id, orcid.org/0000$\underline{0002-4285-0623}$

2 Universitas Islam Negeri Jakarta, Indonesia, asyari.hasan@uinjkt.ac.id, orcid.org/0000-0003-0973-8602

${ }^{3}$ Institut Agama Islam Negeri Batusangkar, Indonesia, alimin@iainbatusangkar.ac.id, orcid.org/00000001-8853-221X
} 
In a golden age of Islamic government, zakat is able to become an instrument for the welfare of the people because zakat is managed as amanah and professionally (Surur, 2006). The potential of zakat could grow and develop well if zakat is also managed in accordance with legal rules and the context of dynamic socio-economic development. Therefore, the management of zakat is an important factor and determines the success of a zakat institution like BAZNAS in attaining its objective, namely, making zakat become a source of fund and an asset having potentials in community, social, or public empowerment.

Zakat collection and its distribution are two of the main jobs of BAZNAS. There has been a rapid development in the zakat collection and its distribution in BAZNAS at the regency/city level in the province of West Sumatera, particularly in BAZNAS of Tanah Datar Regency, BAZNAS of Agam Regency, and BAZNAS of Bukittinggi City. The research has found that the national average amount of zakat that has been able to be collected in Indonesia was less than $1 \%$ of its potency (Canggih, Fikriyah and Yasin, 2017). Meanwhile, the amount of zakat collection of the three BAZNAS offices in the province of West Sumatera was far above the national average, it has reached $5 \%-15 \%$ of its potency. The success in zakat collection and its distribution in a BAZNAS office is surely inseparable from the collection and distribution management which is professionally done.

Empirical studies of zakat are viewed from various aspects. Previous research has discussed zakat and poverty alleviation (Arif, 2018; Hoque, Khan, and Mohammad, 2015; Jaelani, 2015; Shaikh, 2016; Shirazi and Fouad bin Amin, 2009), effectiveness and efficiency of zakat institutions (Al-Ayubi, Ascarya and Possumah, 2018; Wahab and Rahman, 2011), constraints faced by zakat institutions (Asnaini, 2011), and management of zakat institutions (Ahmad Razimi, Romle, and Muhamad Erdris, 2016; Aziz, Jamil, Ismail and Rahman, 2013; Hudayati and Tohirin, 2010; Saidurrahman, 2013). However, no studies have been found that specifically examine the management model of collecting and distributing zakat, especially the zakat management model in regency/city BAZNAS.

The research of Huda et al. (Huda, Anggraini, Ali, Mardoni and Rini, 2014) stated that there are three kinds of priority problems and zakat management solutions, they are divided based on stakeholder management institutions, namely (a) government, (b) zakat management organization, and (c) muzakki (zakat giver) and mustahik (zakat beneficiary). The other research (Sari, Bahari and Hamat, 2013) explains that since 1999 zakat management in Indonesia has been more systematic. But however, zakat management in Indonesia is not optimal and has not been able to explore the huge potential of zakat in this country with the largest Muslim population. According to the research, these weaknesses come from the community (sociological aspects), the government (regulatory aspects), and the amil (management aspects).

Good management is an absolute matter in zakat management because it would give impact on the accomplishment of the program on the whole, which includes the collection and distribution program. This study aims to describe the managerial steps taken by BAZNAS in the regency/city in the province of West Sumatera particularly the BAZNAS of Tanah Datar Regency, BAZNAS of Agam Regency, and BAZNAS of Bukittinggi City in the course of zakat collection and its distribution. So that, these steps could serve as reference for other regency/city level BAZNAS offices in managing zakat in their respective regions. 


\section{Literature Review}

The word zakat is a derived form of the word zaka, which has the meanings of 'blessing', 'growth', and 'chastity' (Anis, Muntashir, Al-Syawaliyah and Muhammad Khalfullah Ahmad, 1972). As a term, zakat is the obligatory payment of a muslim to the needy to physically and spiritually purify his or her wealth after it reaches its haul (required amount possessed) and nisab (required length of time of possession) (Jum'ah, 2000). It is unallowable for one who claims to believe in Allah and in the last day to be reluctant to do acts of charity (including by means of paying zakat) (Yusuf, 1979).

Zakat has two straightforward benefits. Firstly, the payer himself gets purification and spiritual benefits. Secondly, zakat helps those who are not able to fulfill their needs independently. For e.g. orphans, widows, handicaps, poor people, etc. (Usmani and Qazi, 2008). Zakat's spiritual dimension cannot be underestimated, particularly since it holds a great deal of psychological as well as material importance to Muslims. Those who give and receive zakat are bound together through this mutual love encouraged by the distribution of wealth. In the ideal Islamic society, the poor are admonished against begging. Therefore, zakat plays the important role of disbursing wealth while preserving the needy person's integrity. Receiving zakat without the humiliation of begging evokers a sense of purity and allays feelings of envy, jealousy, and hatred toward the rich (Esposito, 1995). In social and economic contexts, it aims to reduce the socio-economic differences and solve the socio-economic problems, so it is considered to be the most important socio-economic institution and known as a means of achieving social justice (Ismail, 2013; Oran, 2009; Sarif and Kamri, 2009).

In some present Islamic countries like Saudi Arabia, Sudan, Libya, and Pakistan, zakat is made obligatory by a state law of zakat obligation (wajib qanuniyyan) and fully managed by authorized institutions. Meanwhile, some other Islamic states do not make zakat obligatory based on a state law; instead, it is left to individual awareness, meaning that individuals are given freedom to decide whether or not to pay zakat as religious obligation (wajib diniyyan) (Taufiq, 2006). The governance structure of zakat management depends fully upon the perception of the state towards the role of zakat system. To those who position zakat system as complementary to the fiscal policy, they would treat zakat institution as the part of governmental administration, and vice versa.

In Indonesia, the zakat collection is voluntary in nature, meaning that, as previously mentioned, it is left to the individual's awareness of his or her obligation as muslim. Then, zakat is collected by governmental and non-governmental (or private) institutions, but Kasri and Putri (Kasri and Putri, 2018) stated that nongovernment institutions in Indonesia were flexible enough to run programs.

Management of zakat collection and its distribution can be reinforced too by using financial technology (Aulia Rachman and Nur Salam, 2018; Mulyadi, Hakim, Mulazid, Supriyono and Meiria, 2018; Rahman, Dahlan, Nurasyikin, Awang and Mahmood, 2015), but not all of zakat agencies can apply this technology. Availability of quality human resources is the main factor to be able to realize it. The quality human resources can improve not only zakat collection and its distribution but also zakat management in general.

\section{Method}

The research used the case study method. The research was conducted in three regency/city BAZNAS offices in Sumatera Barat, namely Tanah Datar Regency, 
Agam Reegency, and Bukittinggi City. The sources of the research data were head officials, secretariat staffs, field personnel, Zakat Collecting Unit (UPZ) officials, and related documents of BAZNAS. The researcher collected detailed information using a variety of data collection procedures. The data were obtained by using interviews, observations, and documentations. The analysis of the data in the qualitative research was a process of seeking and systematically arranging the data obtained from interview results, field notes, and documentations by way of organizing the data into categories, breaking them down into units, making syntheses, constructing them into patterns, selecting the data that were important and to be studied, and drawing conclusions.

\section{Results and Discussion}

The management of zakat collection and its distribution in the regency/city level BAZNAS in West Sumatera, particularly the Tanah Datar, Agam, and Bukittinggi BAZNAS, is done through a POSCAC management. This management have a series of activities. The first character of POSCAC is $\mathrm{P}$ (planning). The planning of zakat collection and its distribution can be described as follows.

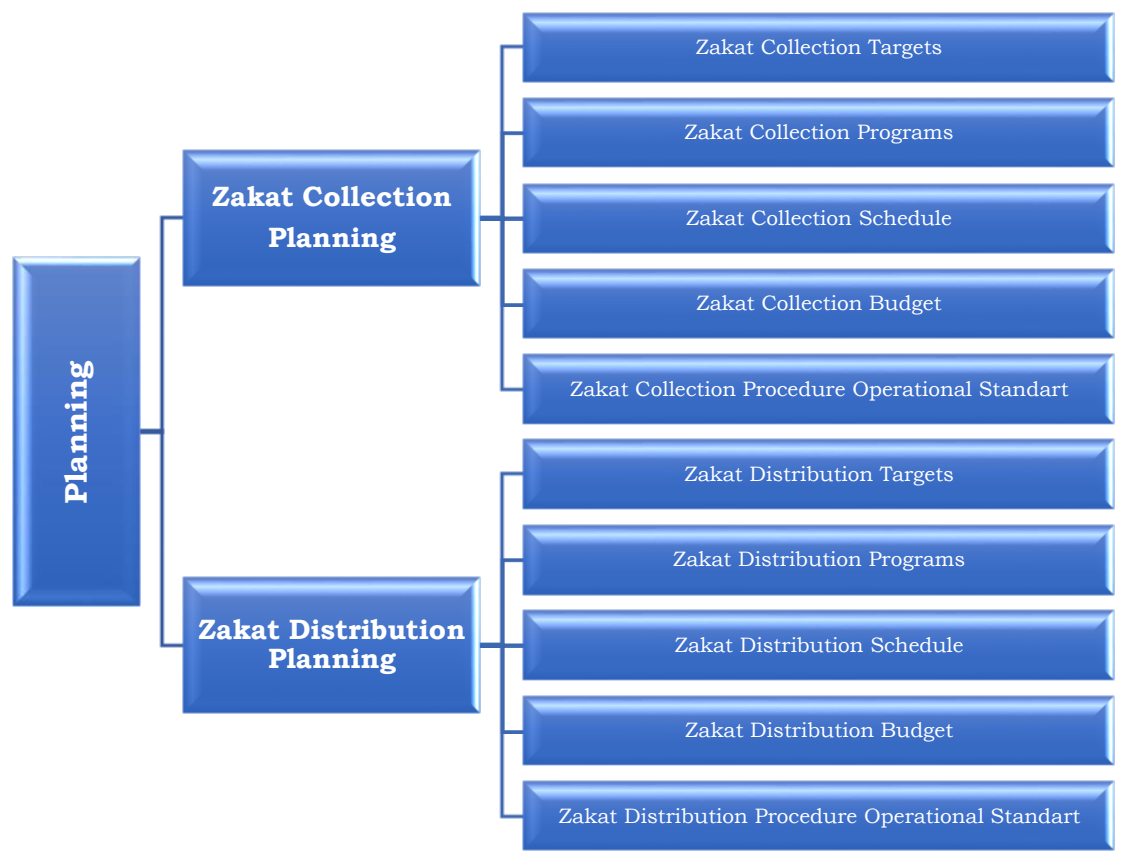

Planning of POSCAC management means planning of zakat collection and its distribution. Zakat collection planning covered five aspects, they are planning of zakat collection targets, programs, schedule, budget, and procedure operational standart, whereas zakat distribution planning covered five aspects too, they are planning of zakat distribution targets, programs, schedule, budget, and procedure operational standart.

The first activity done by the officers of the regency/city level BAZNAS in the planning step is holding a work meeting to discuss the planning of zakat collection and its distribution. The meeting is attended by all elements of the officers and secretariat staffs. The meeting discusses the targets to be attained of zakat 
collection and its distribution. The meeting also discusses the programs to be run to actualize it, maps zakat resources and regions, makes the activity schedule, and so on. With the resulting decisions of the meeting afterwards passed on to the division of zakat collection and the division of zakat distribution to be followed up.

Programs of zakat collection from muzakki who are civil servant are held in coordination with regional government. The commitment and actual role of regional government in assisting the zakat collecting make the job of BAZNAS in collecting zakat from civil servant become lighter. Besides programs of collecting zakat from civil servant, BAZNAS also makes programs of zakat collection from muzakki who are not civil servant, namely, those who are business people, merchants, farmers, and so on. Differing from zakat collection from civil servant, zakat collection from muzakki who are not civil servant requires maximum effort in order that they are willing to give their zakat to the needy through BAZNAS. Programs of zakat collection from those who are not civil servant are designed and conducted independently by BAZNAS.

The second character of POSCAC is O (organizing). The organizing of zakat collection and its distribution can be described as follows.

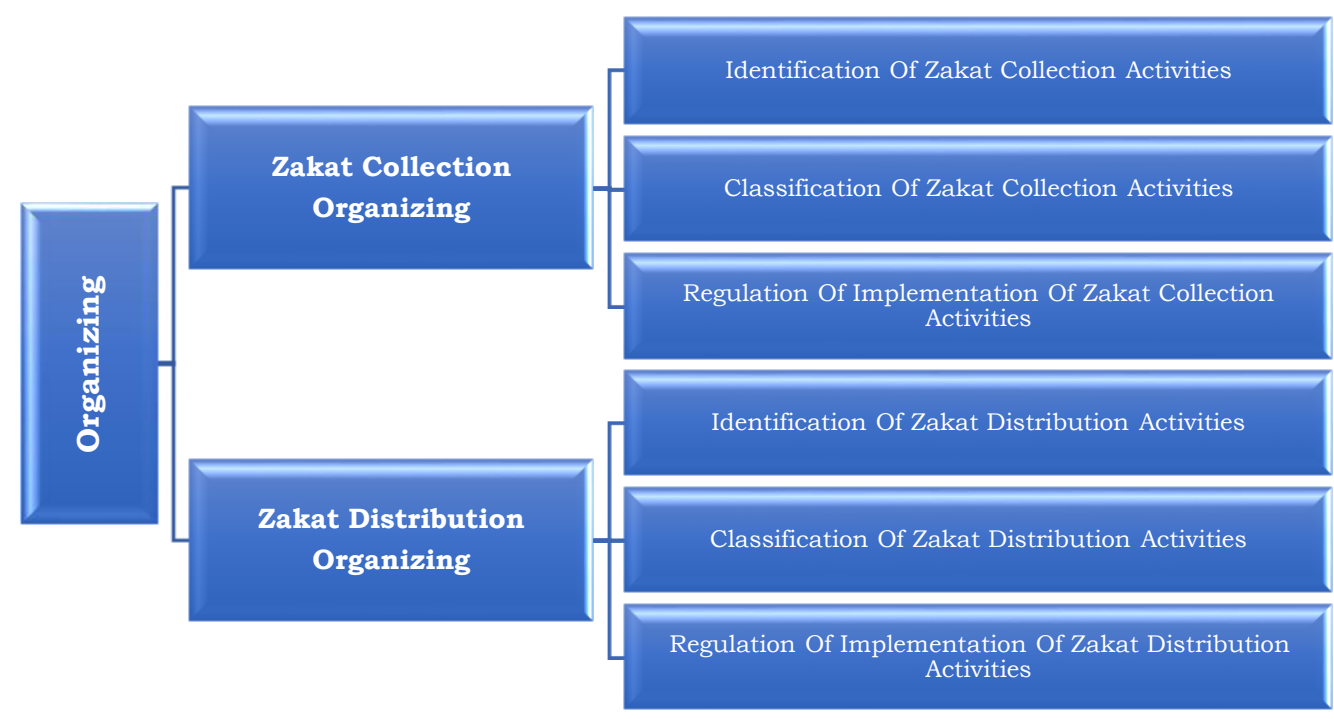

Organizing of POSCAC management means organizing of zakat collection and its distribution. Zakat collection organizing covered three aspects, they are identification of collection activities, classification of collection activities, and regulation of implementation of collection activities. As for zakat distribution organizing covered three aspects too, they are identification of distribution activities, classification of distribution activities, and regulation of implementation of distribution activities The steps of organizing are taken by the division of zakat collection and division of zakat distribution of regency/city level BAZNAS. At this stage, officials of the two divisions organize the activities to be done in the course of running the collection and distribution programs. BAZNAS forms a work team to be responsible for the activities. In organizing the activities, the officials of BAZNAS synergize with the secretariat staffs. 
The third character of POSCAC is S (staffing). The staffing of zakat collection and its distribution can be described as follows.

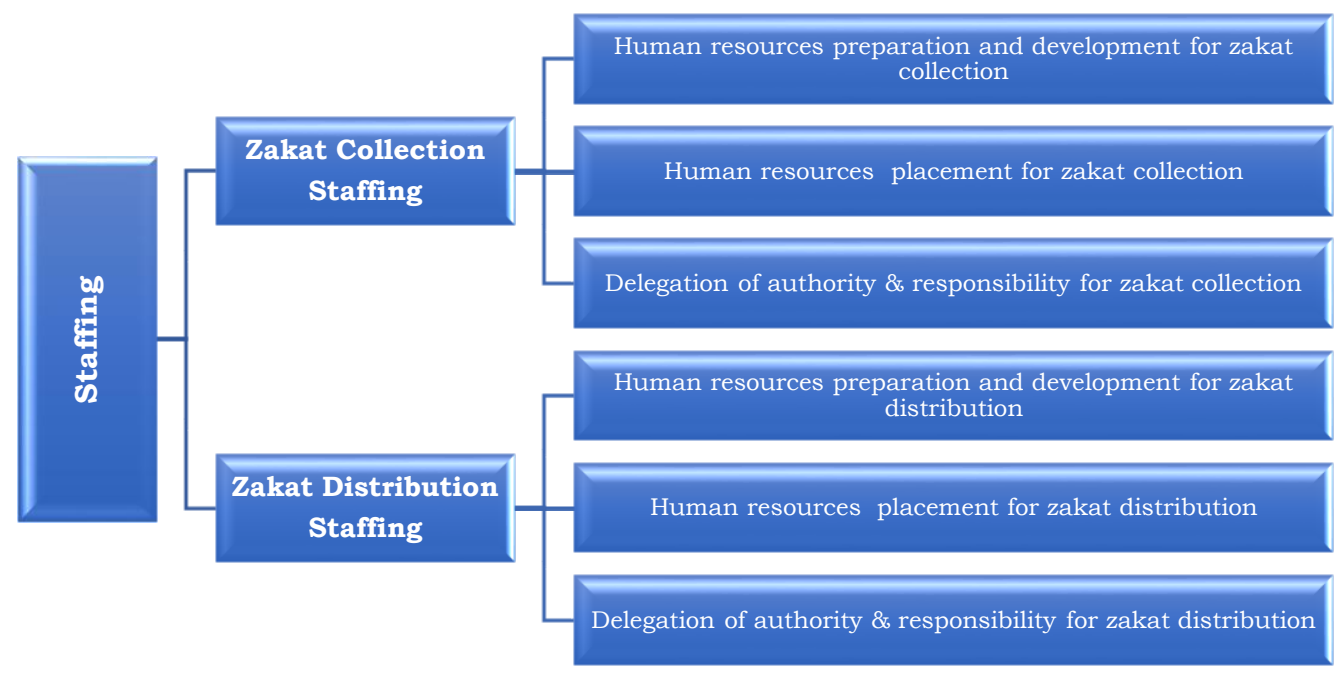

Staffing of POSCAC management means occupying. Staffing of zakat collection and its distribution is the right human resources placement process to carry out activities in order to collect zakat and distribute it. Zakat collection organizing covered three aspects, they are human resources preparation and development for zakat collection, human resources placement for zakat collection, and delegation of authority and responsibility for zakat collection. Zakat distribution organizing covered three aspects too, they are human resources preparation and development for zakat distribution, human resources placement for zakat distribution, and delegation of authority and responsibility for zakat distribution.

The fourth character of POSCAC is $\mathrm{C}$ (coordinating). The coordinating of zakat collection and its distribution can be described as follows.

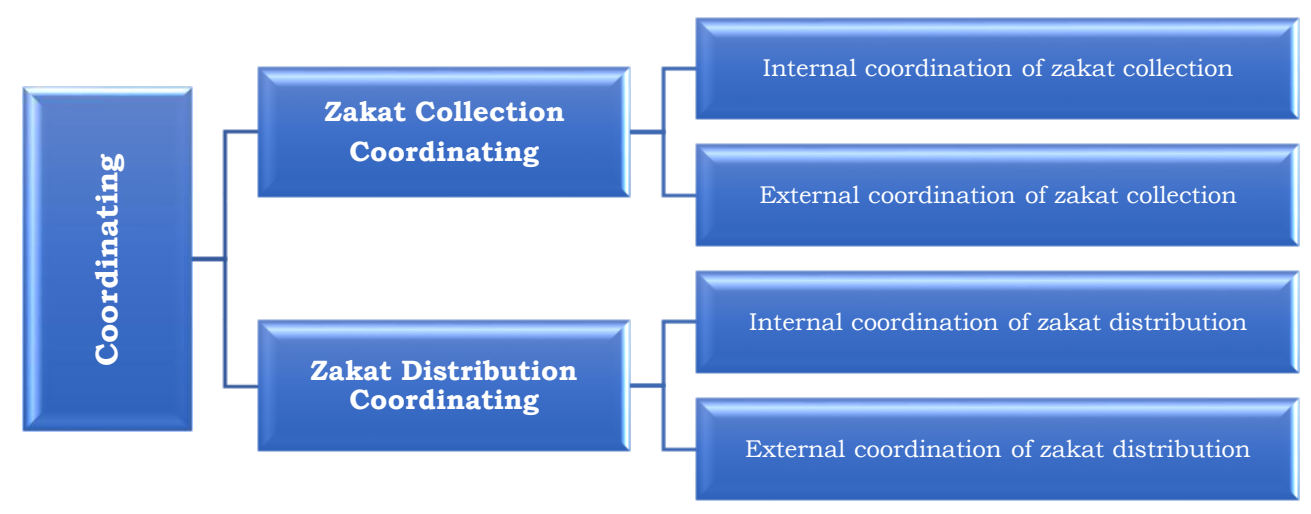


Coordinating of POSCAC management means establishing effective communication with related elements, internal and external, to achieve the purpose of zakat collection and its distribution. Coordination of zakat collection and its distribution covered two aspects, they are coordination with internal elements and coordination with external elements of BAZNAS. In this context, internal coordination is coordination between internal elements of BAZNAS, they are head officers, division officers, secretariat staffs, and volunteers. As external coordination is coordination with external elements of BAZNAS of regional government, government agencies, religious institutions, schools/madrasahs, and other related elements.

The fifth character of POSCAC is A (actuating). The actuating of zakat collection and its distribution can be described as follows.

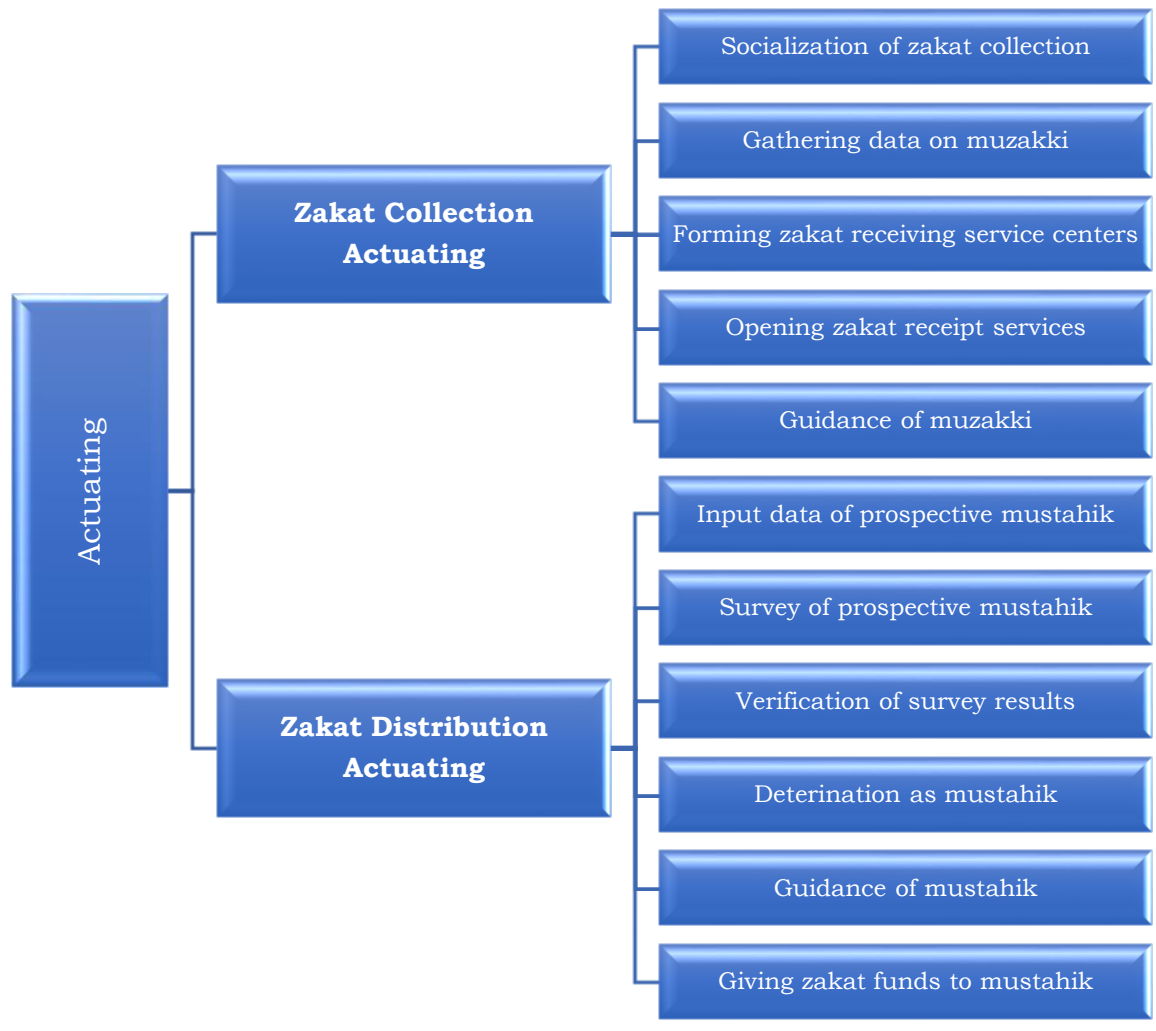

Actuating of POSCAC management means operating. As for the activities actuated in the course of zakat collection, they are socialization, gathering data on muzakki, forming receiving zakat service centers, opening zakat receipt services, and guidance of muzakki. The activities actuated in the course of zakat distribution are input data of prospective mustahik, survey of prospective mustahik, verification of survey results, determination as mustahik, guidance of mustahik, and giving zakat funds to mustahik.

The socialization of zakat is done as effort to educate society members in order that they have awareness of the obligation of paying zakat and are willing to pay their zakat through the officially appointed institution, namely BAZNAS. The 
socialization needs to be done in order that the zakat potential could be gathered from muzakki to the maximum, so that it could be used to actualize the welfare of the people concerned. The socialization of zakat by regency/city level BAZNAS is done in a sustainable way.

The socialization to muzakki who are civil servant is done at various government institutions, universities, schools, and so on. BAZNAS, through its socialization team, invites muzakki who are civil servant to pay their zakat in full $(2.5 \%$ of what is earned) to BAZNAS. The socialization team distributes forms to be filled in as statements of their willingness to pay their zakat through BAZNAS. Socialization of rules of zakat is also delivered to muzakki who are not civil servant like members of such organizations as those of business people, merchants, and people with the same professions, farmers, and members of the public in general. The socialization is done through religious lecture at mosques, door to door, and so on.

Besides, BAZNAS officers also socialize zakat non-formally in every opportunity. As a result, more muzakki started to pay their zakat to BAZNAS. The main challenge that BAZNAS is confronted with in its socialization of zakat to muzakki who are not civil servant is changing their habit of directly giving zakat to close friends or people around them into willingness to pay their zakat through BAZNAS because often direct giving of zakat to whoever receives it does not hit the target, meaning that it is often given to people who actually should not receive it while, on the contrary, those who have the right to it, instead, often do not receive it. Therefore, BAZNAS needs to prepare socialization material appropriate for bringing awareness to people so that they are willing to pay their zakat through BAZNAS.

The socialization team consists of two to three people. The team members are BAZNAS head officials who are competent in giving both the theoretical and practical aspects of such socialization. Besides its head officials, BAZNAS also involves other parties in the socialization, like government and ulama. Besides face-to-face socialization, BAZNAS also conducts socialization through mass media like local television, radio, newspapers, and so on. The socialization material delivered is related to making the people concerned aware of their obligation of paying zakat, the right way to do it, namely, through amil, and the way BAZNAS works as amil zakat.

The socialization of zakat and muzakki's statement of willingness to pay zakat to BAZNAS are followed up with the formation of zakat receiving service centers. Zakat Collecting Unit (Unit Pengumpul Zakat 'UPZ') is an organizational unit formed by BAZNAS at a work unit or regional unit and assigned with the job of zakat receiving service from muzakki who pay their zakat. The formation of UPZ has the purpose of making things run smoothly and making them convenient for muzakki in paying their zakat. UPZ is formed at governmental institutions, subdistricts, universities, schools/madrasahs, business companies, mosques, and so on. Officials of UPZ are appointed through a written decree of the head of BAZNAS in accordance with candidates' names proposed by the institution, school, or mosque concerned. Muzakki who do not have an UPZ for their own needs yet could individually pay their zakat directly to BAZNAS or through various forms of zakat receiving service that has been provided by BAZNAS, namely, zakat counters, marketing staffs, zakat boxes, muqayyadah collecting, or directly submitted by muzakki to BAZNAS bank account. 
In gathering zakat, BAZNAS does it in the following ways, regular gathering and independent gathering. Regular gathering, namely, gathering zakat through UPZ that has been formed, which is responsible for only receiving zakat paid by muzakki, with the zakat thus collected being afterward submitted to the BAZNAS bank account or directly delivered to the BAZNAS office. Independent gathering, namely, gathering zakat from muzakki/members of the public in general who are willing to pay their zakat through BAZNAS, with the gathering done through various forms of zakat receiving service. Muzakki who have paid their zakat through the regency/city level BAZNAS are given further sustainable guidance. It has the purpose to improve their understanding of the zakat obligation and eliminating any doubts in paying zakat through BAZNAS.

As for the activities actuated in the course of zakat distribution, they are initiated by input data of prospective mustahik of each region. BAZNAS asks that the each UPZ creates a list of prospective mustahik names in its region. BAZNAS also inputs prospective mustahik data based on proposals submitted individually/collectively or based on community reports on emergency conditions. BAZNAS recapitulated prospective mustahik data and then grouped them according to the division of regions to be surveyed. After all, BAZNAS surveys the real conditions of prospective mustahik and verifys results of survey. The survey is carried out by field officers to get complete information about the actual conditions of prospective mustahik, and to ascertain whether the prospective mustahik really has the right to receive zakat in accordance with the stipulated conditions and criteria.

The results of the survey conducted by field workers were submitted to the distribution division to be verified by the verification team. This team will recommend prospective mustahik to be determined as mustahik through the Decree of the Head of the Regency/City BAZNAS. BAZNAS determinates mustahik who will receive zakat based on data veryfication. For those who are not eligible, the administrators make a letter containing information and explanation of why they cannot receive zakat. All mustahik that have been determined as zakat recipients, are invited by BAZNAS to come at a time and place that has been determined to be given guidance on how to manage zakat funds and subsequently the distribution of zakat funds to mustahik is carried out.

The last character of POSCAC is $\mathrm{C}$ (controlling). The controlling of zakat collection and its distribution can be described as follows. 


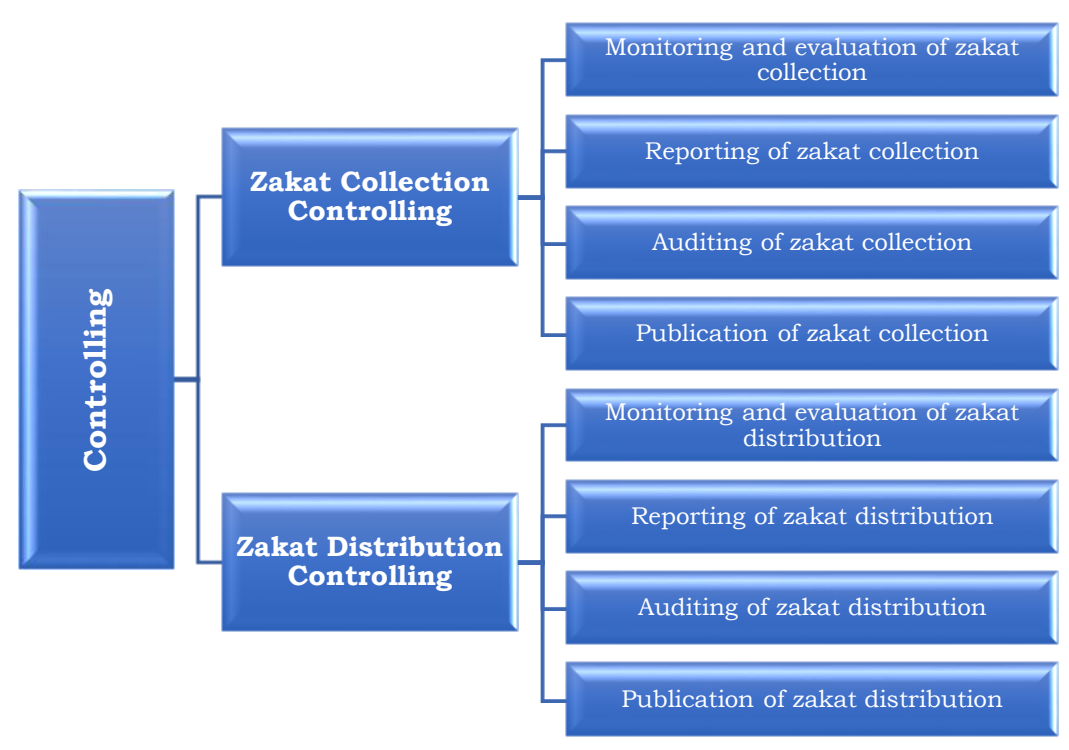

The collection and distribution of zakat are controlled by periodic monitoring and evaluation (of the related activities done; the amount of zakat gathered and given, the zakat collection and distribution development in each UPZ). The collection division of the regency/city level BAZNAS also makes zakat reception reports (consisting of monthly reports, semester reports, and annual reports) submitted to the officials. At the end of the year, the zakat collection and distribution activities on the whole are reported to the Regent, Regional Council of People's Representatives (DPRD), and BAZNAS of the province as a form of stating accountability. Besides, the regency/city level BAZNAS also has a report of the zakat collection and distribution activities and the amount of zakat fund transparently. The report is published in various mass media.

Based on research findings that have been described previously, it is clear that zakat collection and its distribution by BAZNAS in the regencies/cities in the province of West Sumatera, particularly in BAZNAS of Tanah Datar Regency, BAZNAS of Agam Regency, and BAZNAS of Bukittinggi City, are taken through a series of activities that could be classified into six functions of management, namely, planning, organizing, staffing, coordinating, actuating, and controlling (POSCAC). By taking the management steps as described above, the regency/city BAZNAS has successfully collected zakat from muzakki in a great amount and distributed it to mustahik, and this amount has continued to grow from year to year.

The results of this study are different from those of Jaelani (Jaelani, 2015) who formulated zakat management in order to eradicate poverty in Indonesia in four management steps, namely planning, implementation, reporting control, and accountability. However, these six management functions (POSCAC) have relevance to BAZNAS functions in carrying out their duties as zakat managers as mentioned in Law No. RI. 23 of 2011. 


\section{Conclusion}

The collection and distribution of zakat in the regency/city BAZNAS are conducted through a series of activities. The management steps of zakat collection and its distribution serve in sequence the six functions of management, namely, planning, organizing, staffing, coordinating, actuating, and controlling (POSCAC). By implementing this management, the regency/city BAZNAS in the province of West Sumatera has been able to collect zakat above the national average amount and distribute it effectively. Therefore, these management steps could serve as reference for other regency/city BAZNAS, particularly for the regencies/cities BAZNAS that have many problems in zakat collection and its distribution in their respective regions.

\section{References}

Ahmad Razimi, M. S., Romle, A. R., and Muhamad Erdris, M. F. (2016). Zakat Management in Malaysia: A Review. American-Eurasian Journal of Scientific Research, $11(6), 453-457$.

Al-Ayubi, S., Ascarya, and Possumah, B. T. (2018). Examining the Efficiency of Zakat Management: Indonesian Zakat Institutions Experiences. International Journal of Zakat, 3(1), 37-55.

Anis, I., Muntashir, A. H., Al-Syawaliyah, A. and Muhammad Khalfullah Ahmad. (1972). Al-Mu'jam al-Wasith Juz 1. Kairo: Dar al-Ma'arif.

Arif, M. (2018). Zakat as a Mode of Poverty Alleviation. International Journal of Economics \& Management Sciences, 06(06).

Asnaini. (2011). Pemetaan Potensi Zakat di Provinsi Bengkulu (Sebagai Upaya Pengembangan Ekonomi Umat). Universitas Islam Negeri Sunan Kalijaga Yogyakarta.

Aulia Rachman, M., and Nur Salam, A. (2018). The Reinforcement of Zakat Management through Financial Technology Systems. International Journal of Zakat, 3(1), 57-69.

Aziz, A. A., Jamil, M. M., Ismail, H., and Rahman, N. A. (2013). the Management of Zakat Institutions in Malaysia. The 5th International Conference on Financial Criminology (ICFC), 122-133.

Canggih, C., Fikriyah, K., and Yasin, A. (2017). Potensi dan Realisasi Dana Zakat Indonesia. Al-Uqud: Journal of Islamic Economics, 1(1), 14-26.

Esposito, J. L. (Ed.). (1995). The Oxford Encyclopedia of the Modern Islamic World. New York: Oxford University Press.

Hoque, N., Khan, M. A., and Mohammad, K. D. (2015). Poverty Alleviation by Zakah in a Transitional Economy: A Small Business Entrepreneurial Framework. Journal of Global Entrepreneurship Research, 5(1).

Huda, N., Anggraini, D., Ali, K. M., Mardoni, Y., and Rini, N. (2014). Prioritas Solusi Permasalahan Pengelolaan Zakat dengan Metode AHP Studi di Banten dan Kalimantan Selatan. Al-Iqtishad, 6(2), 223-238.

Hudayati, A., and Tohirin, A. (2010). Management of Zakah: Centralised vs Decentralised Approach. Seventh International Conference - The Tawhidi Epistemology: Zakat and Waqf Economy, 351-374. Bangi. 
Ismail, N. A. (2013). In Search of Debt Free Economic Development. International Journal of Advances in Management and Economics, 70-79.

Jaelani, A. (2015). Zakah Management for Poverty Alleviation in Indonesia and Brunei Darussalam. Zakat Strengthening for Socio Economic Development. Malang.

Jum'ah, A. bin M. (2000). Mu'jam al-Mushthalahat al-Iqtishadiyyah wa alIslamiyyah. Riyadh: Maktabah al Abiikaan.

Kasri, R. A., and Putri, N. I. S. (2018). Does Strategic Planning Matter in Enhancing Performance of Zakah Organization? Some Insights from Zakah Management in Indonesia. 3(1), 1-21.

Mulyadi, Hakim, A. R., Mulazid, A. S., Supriyono, and Meiria, E. (2018). E-Zakat: Redesign the Collection and Distribution of Zakat. KnE Social Sciences, 3(8), 433.

Oran, A. F. (2009). Zakat Funds and Wealth Creation. Review of Islamic Economics, 13(1), 143-153.

Rahman, A., Dahlan, A., Nurasyikin, S., Awang, B., and Mahmood, A. B. (2015). e-ZAKAT4U Program: Enhancing Zakat Distribution System by Merging with Network-of-Mosque (NoM). International Journal of Management and Commerce Innovations, 3(1), 264-268.

Saidurrahman. (2013). The Politics of Zakat Management in Indonesia: The Tension Between BAZ and LAZ. Journal of Indonesian Islam, 7(2), 366-382.

Sari, M. D., Bahari, Z., and Hamat, Z. (2013). Review on Indonesian Zakah Management and Obstacles. Social Sciences, 2(2), 76-89.

Sarif, S., and Kamri, N. 'Azizah. (2009). a Theoretical Discussion of Zakat for Income Generation and Its Fiqh Issues. Shariah Journal, 17(3), 457-500.

Shaikh, S. A. (2016). Zakat Collectible in OIC Countries for Poverty Alleviation : A Primer on Empirical Estimation. International Journal of Zakat, 1(1), 17-35.

Shirazi, N. S., and Fouad bin Amin, M. (2009). Poverty Elimination through Potential Zakat Collection in OIC-Member Countries: Revisited. The Pakistan Development Review, 48(4II), 739-754.

Surur, N. (2006). Harapan FOZ Terhadap Pengelolaan Zakat di Indonesia. In K. N. Aflah (Ed.), Zakat \& Peran Negara. Jakarta: Forum Zakat.

Taufiq, M. R. (2006). Pengelolaan Zakat di Negara-Negara Islam. In K. N. Aflah (Ed.), Zakat \& Peran Negara. Jakarta: Forum Zakat.

Usmani, M. I. A., and Qazi, B. A. (2008). Guide to Zakat: Understanding and Calculation. Karachi: Maktaba Ma'ariful Qur'an.

Wahab, N. A., and Rahman, A. R. A. (2011). Efficiency of zakat institutions in Malaysia and its determinants. 8th International Conference on Islamic Economics and Finance, 1-19.

Yusuf, A. (1979). Kitab al-Kharraj. Beirut: Dar al-Ma'rifah. 